Tomasz Szczygieł

Uniwersytet Śląski w Katowicach e-mail: tomasz.szczygiel@us.edu.pl

telefon: 604449759

DOI: 10.15290/mhi.2017.16.02.07

\title{
Prawnicy "starej nadbudowy" w „nowej bazie", czyli o problemie kodyfikacji prawa karnego materialnego Polski Ludowej początku lat pięćdziesiątych
}

\begin{abstract}
SUMMARY
"Old substructure" lawyers in a "new base" the problem of codification of Polish criminal law in the Polish Peoples Republic at the beginning of the fifties

The article focuses on the problem of criminal law codification at the beginning of the Polish Peoples Republic. It shows that there were not many lawyers at that time who had given thought to criminal law in the context of communist law theory. It also describes, that the communist theory of criminal law was not an instrument that would allow to prepare a new "communist criminal code", because it did not possess correct solutions for the new project. Despite this fact, for political and ideological reasons, the process of codification started in Poland at the end of 1950. The first part of the code was ready by the end of 1951, but the entire code was not completed until 1956.
\end{abstract}

Key words: criminal law, codification, Polish Peoples Republic

Słowa kluczowe: prawo karne, kodyfikacja, Polska Rzeczypospolita Ludowa

\section{Wprowadzenie}

Staraniem kolejnych rządów Polski międzywojennej oraz przede wszystkim utworzonej w 1919 r. Komisji Kodyfikacyjnej powstało wiele aktów prawnych składających się na rodzimy system prawny. Do nich niewątpliwie należy zaliczyć kodeks postępowania karnego z 1928 r. oraz kodeks karny z 1932 r. Wraz z kodyfikacją prawa karnego wojskowego, tak materialnego z 1932 r., jak i procesowego z 1936 r., oraz prawa o wykroczeniach z 1932 r., tworzyły one 
wyczerpujący i stojący na bardzo wysokim poziomie zbiór aktów prawnych z dziedziny karnistyki.

Z tym dorobkiem przyszło się „zmierzyć” nowej władzy ludowej, która od połowy $1944 \mathrm{r}$. starała się tworzyć nową socjalistyczną rzeczywistość, także w sferze prawnej. Traktując prawo karne jako synonim prawa w ogóle okresu dokonującej się rewolucji, Polska Ludowa musiała stanąć przed problemem adekwatności prawa karnego, $\mathrm{w}$ tym przede wszystkim kodeksu karnego z 1932 r., tak ze względów ideologicznych jak i praktycznych. Odpowiedź na pytanie, czy była ona już wówczas zdolna zmierzyć się z tym co „odziedziczyła", a przede wszystkim czy miała do tego odpowiednich ludzi, jest celem niniejszej pracy.

\section{Kodyfikacja sprawą "doniosłą" i "dojrzałą" do realizacji}

Kwestia kodyfikacji prawa karnego po 1944 r. stała się aktualna stosunkowo szybko, bo już w połowie 1947 r. To właśnie wówczas w Ministerstwie Sprawiedliwości zaczęły powstawać pierwsze komisje, złożone przede wszystkim z pracowników tegoż ministerstwa ${ }^{1}$. Na kolejnych posiedzeniach tych ciał rozpatrywano szereg zagadnień z zakresu prawa karnego, a wśród nich: materialne określenie przestępstwa, analogia $\mathrm{w}$ prawie karnym, przestępstwa gospodarcze, przestępstwa przeciwko pokojowi i ludzkości oraz zagadnienia systematyki części szczególnej². $\mathrm{W}$ oficjalnej prasie prawniczej publikowano pierwsze teksty poświęcone tym zagadnieniom i reformie prawa karnego w ogóle ${ }^{3}$. I chociaż problematyka ta sięgająca połowy 1949 r. zasługuje na poświęcenie jej osobnej uwagi, to jednak już teraz i na użytek niniejszej pracy warto skontestować, że okres 1947-50 stanowił jedno wielkie nieporozumienie. Większość bowiem prawników biorących udział w spotkaniach w Ministerstwie Sprawiedliwości - zwłaszcza tych z zewnątrz - sprawiała wrażanie jakby kształtująca się po 1944 r. rzeczywistość nie miała wywrzeć istotnego znaczenia na kształt prawa karnego. Koncentrując się na udoskonalaniu, względnie unifikowaniu w ramach kodeksu nowych rozwiązań

1 Zarządzenie z dnia 5 maja 1947 r. (UR. 200/47/Kod. K) - Archiwum Akt Nowych, Ministerstwo Sprawiedliwości w Warszawie (dalej: AAN.MS), sygn.285/1937; Zarządzenie z dnia 24 września 1947 r. (UR.200/47/Kod. K), ibidem.

2 S. Kalinowski, Uwagi dotyczące systematyki części szczególnej kodeksu karnego, (maszynopis), s. 6 (AAN.MS. sygn.285/1941); Przestępstwa gospodarcze. Projekt wstępny (AAN.MS. sygn.285/1942); Przestępstwa przecizwo niepodległości, całości i ustrojowi Polski Ludowej (projekt wstępny wraz z uzasadnieniem), ibidem.

3 L. Lernell, Kodyfikacja czy reforma prawa karnego?, "Demokratyczny Przegląd Prawniczy” (dalej: DPP) 1947, nr 4; idem, Uwagi o nowelizacji i kodyfikacji prawa karnego. Czy konieczna reforma części ogólnej k.k.?, DPP 1947, nr 10; S. Śliwiński, W sprawie reformy prawa karnego. Nowelizacja przepisów dotyczacych zasad odpowiedzialności, DPP 1947, nr 11. 
prawnych, dawali wyraz przekonaniu, że o szerokiej reformie prawa karnego materialnego, przeprowadzonej $\mathrm{w}$ duchu komunistycznej ideologii, nikt z nich wówczas nie myślał. Po 1950 r. tego rodzaju postawy miały stanowić uzasadnienie zarzutów o rzekomym "niezrozumieniu" i „niedojrzałości ideologicznej". Co ciekawe, objawy dezorientacji wykazywali również czołowi przedstawiciele resortu sprawiedliwości z Henrykiem Świątkowskim i Leszkiem Lernellem na czele ${ }^{4}$. Świątkowski utożsamiał bowiem „kodyfikację" z inkorporacją do k.k. z 1932 r. nowych przepisów. Lernell początkowo wyrażał pogląd, że wystarczą stosunkowo niewielkie "korekty” części ogólnej i „uzupełnienia” części szczególnej kodeksu Makarewicza o przepisy szczególne wydane po 1944 r. ${ }^{5}$ To z kolei wskazywało na brak zdecydowanej postawy najwyższych czynników politycznych w tym zakresie, która wskazywała na pewnego rodzaju "stan zawieszenia", jeżeli chodzi o problematykę kodyfikacji, wywołany koncepcją formalnej ciągłości ustawodawstwa międzywojennego, jednak $\mathrm{w}$ zupełnie odmiennej sytuacji politycznej, społecznej i gospodarczej ${ }^{6}$. Igor Andrejew w 1963 r. określił ten okres mianem „scalania", "reformy" i „nowelizacji”, czym dawał do zrozumienia, że nie było wówczas zdecydowania w zakresie problematyki kodyfikacji prawa karnego materialnego ${ }^{7}$.

Złudzenie wywołane dynamiką przemian ustrojowych oraz niewątpliwą grą pozorów nowej władzy, także jeśli chodzi o podejście do istniejącego prawa karnego, której ulegli niemal wszyscy zaangażowani w problematykę kodyfikacji prawa karnego, stosunkowo szybko prysnęło. Okres 1947-1950 jako wyraz „niedojrzałości” i słabości nowej władzy w podejściu do zagadnienia kodyfikacji prawa karnego będzie podlegał zapomnieniu.

Niewątpliwie zdano sobie sprawę z potrzeby przeprowadzenia szerokiej reformy prawa karnego, a dogodnym ku temu momentem było „zdemaskowanie i zlikwidowanie odchylenia prawicowo-nacjnalistycznego", po I Zjeździe PZPR, które zapowiadało „nowe otwarcie” we wszelkich sferach ówczesnej rzeczywistości, także tej prawnej. Tak też się stało, a wstępem do tego miała być kampania przygotowawcza do I Kongresu Nauki Polskiej, która skutkowała w drugiej połowie 1950 r. licznymi konferencjami teoretyków i praktyków, poświęconymi zagadnieniom prawa sądowego, $\mathrm{w}$ tym prawa karnego ${ }^{8}$.

4 Podobnie D. Maksimiuk, Z problematyki kodyfikacji prawa karnego materialnego początków Polski Ludowej, „Miscellanea Historico-Iuridica” (dalej: MHI) 2009, t. 7, s. 144.

5 Ibidem, s. 144-145.

6 A. Lityński, O prawie i sądach początków Polski Ludowej, Białystok 1999, s. 126-127; A. Stawarska-Rippel, Co czynić ze starym prawem? Problem ciagłości prawa sądowego w początkach Polski Ludowej, MHI 2004, t. 5, s. 107-112.

7 I. Andrejew, Nowy kodeks karny. Z rozważań nad projektem, Warszawa 1963, s. 18-19.

8 Referaty i przebieg obrad w zakresie prawa karnego zostały zamieszczone w broszurze wydanej przez Komisję konsultacyjno-Naukową pt. Stan nauki prawa karnego. Konferencja teoretyków i prakty- 
Problematykę kodyfikacji prawa karnego podjęło na początku września 1950 r. Ministerstwo Sprawiedliwości, które wystąpiło do czynników rządowych z inicjatywą rozpoczęcia. W piśmie do Prezydium Rządu pokreślono, że sprawa kodyfikacji prawa karnego stanowi „zagadnienie pilne i doniosłe z punktu widzenia demokratyzacji naszego ustawodawstwa, praktyki wymiaru sprawiedliwości oraz rozwoju nauki marksistowskiej"'. Apel ministerstwa do czynników rządowych zawierał również bardzo konkretną ocenę dotychczasowego stanu prawnego w zakresie prawa karnego. Nie tylko uznano kodeks z 1932 r. za "kompromis” między tendencjami liberalno-burżuazyjnymi, a faszystowskimi $\mathrm{w}$ prawie karnym, ale przede wszystkim wyraźnie stwierdzono jego niedostosowanie do aktualnej rzeczywistości.

Ministerstwo nie tylko wystąpiło z wnioskiem do Prezydium Rządu, przygotowało projekt stosownej uchwały, na której podjęcie liczyło, ale także przedstawiło plan i chronologię prac kodyfikacyjnych ${ }^{10}$. Decyzja Prezydium Rządu była dla ministerstwa pozytywna i 27 września 1950 r. została podjęta stosowna uchwała ${ }^{11}$. Na podkreślenie zasługuje okoliczność, że Prezydium wyznaczyło termin ukończenia prac na dzień 1 września 1951 r., a nie jak wnioskowało ministerstwo na 1 lipca tegoż roku ${ }^{12}$ oraz zobowiązało ministra do przeprowadzenia w prasie szerokiej dyskusji nad węzłowymi zagadnieniami ${ }^{13}$.

Kluczowy fragment uchwały Prezydium Rządu brzmiał: „Uznać za sprawę pilną i konieczną opracowanie nowych kodeksów Polski Ludowej - karnego i cywilnego". Takie postawienie sprawy sprawiło, że o wystąpieniu w przyszłości jakichkolwiek nieporozumień w gronie członków ciał odpowiedzialnych za reformę prawa karnego PRL nie mogło być już mowy. Cel był jasny, co też Leszek Lernell wyraził dobitnie stwierdzając: „Zadanie nasze nie polega na inkorporacji, tj. wcieleniu istniejących przepisów rozrzuconych w różnych aktach ustawodawczych do istniejącego systemu kodeksowego. Nie polega ono

ków prawa karnego. Materiały z prac przygotowawczych do I Kongresu Nauki Polskiej, Warszawa 1951. Zob. także P. Fiedorczyk, Z dziejów stalinizacji polskiej nauki prawa. Komisja Konsultacyjno-Naukowa przy Ministrze Sprawiedliwości (1949-1951), [w:] Konstytucjonalizm, Doktryny, Partie Polityczne. Księga dedykowana Profesorowi Andrzejowi Ziębie, red. R. Kłosowicz, B. Kosowska-Gąstoł, G.M. Kowalski, T. Wieciech, Ł. Jakubiak, Kraków 2014, s. 261-264.

9 Pismo Henryka Świątkowskiego zatytułowane „W sprawie kodyfikacji prawa karnego", prawdopodobnie z 4 września 1950 r., s. 1 (AAN.MS. sygn.285/1936).

10 Problematyka wstępna części ogólnej kodeksu karnego; Plan organizacyjny (załącznik 2); Wniosek ministra w sprawie projektu uchwaly, ibidem.

11 Uchwała Prezydium Rządu z dnia 27 września 1950 r., w sprawie opracowania nowych kodeksów Polski Ludowej - karnego i cywilnego (Monitor Polski 1950 rok, Nr A-106, poz. 1339).

12 Informacja Stefana Rozmaryna dla Ministra Sprawiedliwości z dnia 30 września 1950 r. w sprawie podjęcia uchwały - AAN.MS. sygn. 285/1936.

13 Ibidem. 
również na komasacji i systematyzacji obowiązujących przepisów w jednym akcie ustawodawczym. Uchwała Prezydium Rządu mówi o wydaniu nowych kodeksów, tj. stworzenie przepisów odpowiadających ustrojowi państwa z uwzględnieniem jego perspektywy rozwojowej, przepisów opartych na nowych podstawach i nowych w swej formie" ${ }^{14}$. Kodyfikacja stała się sprawą wagi państwowej, a dotychczasowe koncepcje reform odrzucone i niebyłe. Okres 1947-1950 jako najwyraźniej „niedojrzały” do tego rodzaju przedsięwzięć został zapomniany, a punktem "0" w oficjalnych dokumentach i prasie stał się odtąd 27 września 1950 r. ${ }^{15}$

Plan prac kodyfikacyjnych zakładał dwutorowe opracowywanie projektu kodeksu karnego. Równolegle z pracami nad częścią ogólną, zakładano opracowywanie poszczególnych rozdziałów części szczególnej. W całym tym niespełna rocznym okresie czasu planowano nie tylko przeprowadzić analizy prawnoporównawcze przepisów innych państw demokracji ludowej, ale także międzyresortowe konsultacje, uzgodnienia z czynnikami politycznymi i prace redakcyjne nad kształtem konkretnych przepisów kodeksu ${ }^{16}$. W tym celu nie tylko powstała przy ministrze kolejna Komisja Kodyfikacyjna ${ }^{17}$, ale także ciało pomocnicze, odpowiedzialne za naukowe opracowywanie problematyki w postaci Komisji Konsultacyjno-Naukowej ${ }^{18}$. Przewidziano również czas na dyskusję publiczną ${ }^{19}$.

Był to plan bardzo ambitny, zważywszy na rozległość problematyki, jaką należało rozważyć $\mathrm{w}$ stosunkowo krótkim czasie. W ministerstwie najwyraźniej zdawano sobie $\mathrm{z}$ tego sprawę, dlatego jeszcze przed ogłoszeniem uchwały Prezydium Rządu z 27 września przystąpiono do gromadzenia materiałów źródłowych (naukowych i prawnoporównawczych), pomocnych przy opracowaniu kodeksu ${ }^{20}$. Konferencja $\mathrm{w}$ tej sprawie odbyła się $\mathrm{w}$ dniu podjęcia uchwały

14 L. Lernell, Z problematyki kodyfikacji prawa karnego. Rozważania ogólne. Tezy, s. 1 (AAN.MS. sygn.285/5476).

15 Projekt kodeksu karnego Polskiej Rzeczypospolitej Ludowej i przepisy wprowadzające, Warszawa 1956, s. 3; M. Rybicki, Informacja o stanie prac kodyfikacyjnych i o przebiegu dyskusji nad projektem kodeksu karnego (do użytku wewnętrznego), s. 10-11 (AAN, MS, sygn. 285/1792); idem, Notatka o projekcie kodeksu karnego (z 1963 r. - T.Sz.) w świetle dyskusji publicznej (AAN, MS, sygn. 285/1791).

16 Załącznik nr 2 do projektu uchwały z 27 września 1950 r., ibidem; Kalendarz prac nad projektem kodeksu karnego (0.34), (AAN.MS. sygn. 285/1936).

17 Odpis zarządzenie Ministra Sprawiedliwości z dnia 1 grudnia 1950 roku (Nr 12/51) w sprawie powołania Komisji Kodyfikacyjnej - (AAN.MS. sygn. 285/1814) Szerzej na ten temat P. Fiedorczyk, op. cit., s. 258-260. Ibidem.

Pismo L. Lernella z dnia 12 września 1950 r. w sprawie zebrania osób zaangażowanych w zbieranie materiałów do nowego k.k., skierowane do Igora Andrejewa, Czesława Bieleckiego, Arnolda Gubińskiego, Stefana Kalinowskiego, Henryka Kempistego, Romana Korab-Zebryka, Zbigniewa Kubeca, Stanisława Pławskiego, Jerzego Sawickiego, Zofii Nyczaj, Zbigniewa Borowicza, sędziego Lisa. Ibidem. 
przez Prezydium Rządu²1. Co więcej, już wcześniej opracowano tezy wstępne do części ogólnej kodeksu22. Było ich trzynaście. Zasługują one na przytoczenie, ponieważ większość wyrażonych w nich problemów stanowiła już element dyskusji w „zapomnianym okresie”, a więc 1947-1950. Bez wątpienia ministerstwo skorzystało $\mathrm{z}$ tamtych doświadczeń. O ile jednak wtedy tego rodzaju poglądy stanowiły przyczynę nieporozumień $\mathrm{w}$ związku $\mathrm{z}$ jak się wydawało potrzebą „niewielkiej reformy i dostosowania kodeksu karnego", o tyle aktualnie stały się one wytycznymi dla nowej kodyfikacji karnej Polski Ludowej. Były to następujące tezy:

1) określenie celów i zadań prawa karnego w okresie budowania podstaw socjalizmu zgodnie ze wzorem radzieckim, czechosłowackim i węgierskim;

2) określenie istoty klasowej przestępstwa jako czynu niebezpiecznego dla interesów mas pracujących Polski;

3) rozstrzygnięcie kwestii dopuszczalności analogii w prawie karnym;

4) sformułowanie zasad odpowiedzialności za przygotowanie i organizowanie spisku i bandy;

5) podkreślenie - zgodnie z klasowym interesem mas pracujących - celów i zadań kary, jako elementu wychowawczego represji karnej;

6) określenie wytycznych wymiaru kary zgodnie z interesem Państwa Ludowego;

7) opracowanie na nowo systemu kar z uwzględnieniem istniejących w ustawodawstwie nowych środków represji (np. obóz pracy i zakaz pobytu z dekretu o Komisji Specjalnej oraz potrącenie z poborów z ustawy o zabezpieczeniu socjalistycznej dyscypliny pracy);

8) rozstrzygnięcie zagadnienia prawa sądu do nadzwyczajnego łagodzenia kary, obecnego w innych ustawodawstwach bloku socjalistycznego, przede wszystkim ZSRR;

9) rozstrzygnięcie kwestii odpowiedzialności karnej nieletnich oraz ustalenie granicy wieku tej odpowiedzialności;

10) odniesienie części ogólnej powszechnego kodeksu do przestępstw wojskowych, najlepiej ujętych w jednym kodeksie;

11) zdefiniowanie w części ogólnej takich pojęć jak „urzędnik”; „mienie państwowe", "mienie społeczne";

12) ponowne określenie przesłanek stosowania środków ochronnych $w$ stosunku do chorych psychicznie i alkoholików. Dotychczasowe podstawy stosowania środków zabezpieczających takie jak wstręt do pracy, zawodowość itp., nie mogą mieć miejsca;

\footnotetext{
21 Pismo L. Lernella z dnia 7(?) września 1950 r. do prokuratora Wojciecha Gawlikowskiego, ibidem.

22 Tezy wstępne cz. ogólnej zostały wysłane do członków komisji spoza ministerstwa 19 października 1950 roku - rękopis pisma Leszka Lernella do Henryka Holdera, Henryka Podlaskiego, Marii Zorskiej, Stanisława Zarakowskiego i Oskara Karlinera. Ibidem.
} 
13) rozstrzygnięcie kwestii dopuszczalności odpowiedzialności za zbrodnię z winy nieumyślnej, zwłaszcza ze względu na przestępczość gospodarczą ${ }^{23}$.

Wskazane obszary miały pomóc w pracach nad częścią ogólną, której opracowanie i przedstawienie powierzono Leszkowi Lernellowi i Stanisławowi Pławskiemu ${ }^{24}$. W przypadku części szczególnej przyjęto nieco inne rozwiązanie. W pierwszej kolejności postanowiono zebrać i opracować materiał prawnoporównawczy, aby następnie przystąpić do sporządzenia referatów i projektów poszczególnych rozdziałów. Naukowe opracowanie niektórych kategorii przestępstw powierzono ośrodkom uniwersyteckim m.in. w Krakowie, Toruniu, Łodzi i we Wrocławiu ${ }^{25}$. W piśmie wystosowanym do wskazanych ośrodków uniwersyteckich czytamy, że materiały miały być „zgromadzone w ten sposób, aby można było na ich podstawie przedstawić postulaty kodyfikacyjne" ${ }^{26}$. Podział zadań między Komisję Konsulatacyjno-Naukową, a „właściwą” Komisją Kodyfikacyjną przy ministerstwie został wyraźnie zaznaczony.

Termin zakreślono do dnia 20 października, jednak następnie został on przedłużony do dnia 15 listopada, na co niewątpliwie musiały mieć wpływ opinie m.in. profesorów Witolda Świdy i Władysława Woltera odnośnie nierealności "głębszego opracowania problemu" „lepszej jakości prac" w pierwszym terminie ${ }^{27}$. Wiemy również, że Ministerstwo Sprawiedliwości wystąpiło do prezesów sądów apelacyjnych i okręgowych o wystosowanie na piśmie do 16 października 1950 r. postulatów pod adresem Komisji Kodyfikacyjnejej. Pismo podobnej treści zostało wysłane również przez Prokuratora Generalnego do właściwych jednostek terytorialnych prokuratury ${ }^{29}$.

Z zachowanych materiałów wynika, że program zbierania oraz opracowywania materiałów z innych państw demokracji ludowej zapoczątkowany na konferencji z 27 września 1950 r., od samego początku natrafiał na trudności

23 Problematyka wstępna części ogólnej kodeksu karnego (załącznik nr 1 do wniosku o podjęcie uchwały w sprawie opracowania nowego kodeksu karnego), (AAN.MS. sygn. 285/1936).

24 Protokół z zebrania pracowników Departamentu Ustawodawczego Ministerstwa Sprawiedliwości uczestniczących w pracach kodyfikacyjnych prawa karnego odbytego z dnia 20 lutego 1951 r., s. 3. Ibidem

25 Pismo prof. W. Świdy z dnia 26 września 1950 r. powołujące się na pismo z ministerstwa z dnia 20 września 1950 r. Nr U 2840/50 K.020/7/1 w sprawie przygotowania materiałów z dziedziny przestępstw przeciwko mieniu prywatnemu; Pismo prof. W. Woltera z dnia 27 września $1950 \mathrm{r}$. oraz 8 października 1950 roku w sprawie przestępstw przeciwko życiu i zdrowiu; Pismo prof. J. Śliwowskiego z dnia 3 października 1950 r., ibidem.

26 Rękopis pisma dyrektora Departamentu Ustawodawczego Ministerstwa Sprawiedliwości L. Lernella z dnia 20 września 1950 r. do prof. W. Woltera, prof. W. Świdy i J. Śliwowskiego. Ibidem; zob. także P. Fiedorczyk, op. cit., s. 267.

AAN.MS. sygn.285/1936; Zawiadomienie W. Woltera o zmianie terminu przewidzianego na przygotowanie materiałów, ibidem. 
finansowe i organizacyjne (problem przygotowania maszynopisów) ${ }^{30} . \mathrm{Z}$ korespondencji kierowników zakładów prawa karnego UJ, UWr, UMK do ministerstwa wynikało bowiem, że natrafiali oni na trudności w zgromadzeniu zagranicznych aktów prawnych i literatury ${ }^{31}$. Bardzo wielu pozycji po prostu nie było $\mathrm{w}$ Polsce. Jeżeli już jakaś książka czy artykuł znajdowały się w kraju, to trzeba było nie tylko wysłać pracownika naukowego, aby się z nimi zapoznał, ale również sporządził ich odpis i tłumaczenie. Nie mogą zatem dziwić prośby prof. W. Świdy i prof. Jerzego Śliwowskiego do ministerstwa o dostarczenie tych materiałów ${ }^{32}$. Chodziło nie tylko o tłumaczenia kodeksów karnych Czechosłowacji i Węgier, ale także podręczników profesorów Hercenzona i Szarogrodzkiego, których nawet $\mathrm{w}$ ministerstwie nie było ${ }^{33}$. W kręgu zainteresowania uczonych były również zmiany legislacyjne w Rumunii, Bułgarii i Albanii ${ }^{34}$.

Problem dostrzegano również w Warszawie, dlatego nie tylko starano się zorganizować bibliotekę w Ministerstwie Sprawiedliwości ${ }^{35}$, ale także - za pośrednictwem Ministerstwa Spraw Zagranicznych - wystąpić do ZSRR, Czechosłowacji, Węgier i innych krajów demokracji ludowej o udostępnienie materiałów ${ }^{36} .30$ października 1950 r. L. Lernell wystąpił do Wydziału Radzieckiego Ministerstwa Spraw Zagranicznych z prośbą o pomoc w dostarczeniu niezbędnych materiałów. Do pisma załączył ich wykaz, który obejmował 43 pozycje ${ }^{37}$. Na podkreślenie zasługuje fakt, że niemal wszystkie z nich to literatura z połowy lat czterdziestych, co w kontekście "pochodu” faz rewolucji proletariackiej nie było bez zaznaczenia i świadczyło o tym, że polskie rozwiązania prawne miały jak najlepiej odpowiadać zdobyczom prawnym tej rewolucji.

Chęć podejścia do prawa karnego z punktu widzenia ,jedynie słusznej nauki" natrafiła na brak przyswajalnych wzorców. Brakowało nie tylko prze-

30 Pismo prof. W. Woltera z dnia 27 września 1950 r. oraz 8 października 1950 roku w sprawie przestępstw przeciwko życiu i zdrowiu (AAN.MS. sygn. 285/1936).

31 W piśmie z 18 października 1950 r. prof. W. Świda zwraca się z pytaniem do ministerstwa, gdzie może zapoznać się z numerem „Izwiestii” z dnia 5 czerwca 1947 r. zawierającego dekret o ochronie mienia prywatnego obywateli ZSRR oraz wszelkiego rodzaju aktami i projektami ustawodawstwa Demokracji Ludowych. We Wrocławiu ich nie było, ibidem.

Pisma prof. J. Śliwowskiego z dnia 3 i 25 października 1950 r. do Ministerstwa Sprawiedliwości, ibidem.

33 Ibidem, s. 2; Odpowiedz ministerstwa na pismo prof. J. Śliwowskiego z dnia 3 października $1950 \mathrm{r}$. (AAN.MS. sygn. 285/1936).

34 Ibidem

35 W pokoju nr 439 ministerstwa zorganizowano bibliotekę podręczną, w której poszczególni pracownicy resortu zaangażowani w prace kodyfikacyjne, mieli pełnić dyżury - Rękopis pisma L. Lernella z 13 października 1950 r., ibidem.

36 Rękopis pisma do ministerstwa spraw zagranicznych z dnia 19 października 1950 roku o wystąpienie do Poselstwa Polskiego w Tiranie w sprawie materiałów do kodyfikacji, ibidem.

37 Odpis pisma L. Lernella do ministerstwa spraw zagranicznych wraz z wykazem poszukiwanej literatury, ibidem. 
kładów aktów normatywnych, ale także opracowań naukowych czy podręczników. Ministerstwo starało się zabezpieczyć dostępne materiały, ale najczęściej były to oryginalne teksty, a nie tłumaczenia ${ }^{38}$. Wielu aktów prawnych i pozycji literatury nie posiadano nawet $\mathrm{w}$ Warszawie ${ }^{39}$. Polskie pozycje były wciąż nieliczne ${ }^{40}$.

Wszystkie terminy ustalone pierwotnym kalendarzem prac upływały ${ }^{41}$. Pierwsze posiedzenie Komisji Konsultacyjno-Naukowej odbyło się 14 listopada $^{42}$. Materiały opracowywane przez ośrodki uniwersyteckie nie były jeszcze gotowe $^{43}$, stąd przedmiotem obrad tego posiedzenia była problematyka części ogólnej ${ }^{44}$. Skład należy uznać raczej za „warszawski”. Kolejne posiedzenia wyznaczano co trzy dni, a więc 17 i 20 listopada $^{45}$. Z dużym prawdopodobieństwem można stwierdzić, że takie przyspieszenie prac miało miejsce również w kolejnych miesiącach. Szczegółów obrad niestety nie znamy, trudno natomiast przypuszczać, że prace posuwały się po myśli ministerstwa. Z pisma Leona Schaffa z 28 stycznia 1951 r. wynika bowiem, że oczekiwania resortu co do tempa prac były co najmniej nierealne. Materiały prawnoporównawcze dotyczące przestępstw przeciwko państwu, których opracowanie miał dokonać, przesłano mu 28 stycznia. Powierzone zadanie miał z kolei wykonać do 20 lutego. L. Schaff stanowczo zaprotestował, wskazując m.in., że „Pracy nie można i nie należy robić po łebkach, bo nie będzie nic warta" ${ }^{46}$. Nie tylko oświadczył, że terminu nie dochowa, ale również, że wątpliwe jest zakończenie pracy do dnia 20 marca, „o ile praca ma być przemyślana i sumiennie wykonana, a nie polegać na automatycznym przepisywaniu norm już istniejących w ustawodawstwie naszym lub obcym" ${ }^{47}$.

38 Rękopis pisma L. Lernella do prof. W. Świdy z dnia 30 października 1950 r.; odpis pisma L. Lernella do prof. J. Śliwowskiego z dnia 6 listopada 1950 r. wraz z wykazem załączników (część ogólna k.k. RSFRR; część ogólna k.k. Czechosłowacji, część ogólna k.k. Węgier, rozdział części szczególnej k.k. RSFRR dotyczący fałszu dokumentów i odpowiedni z k.k. Bułgarii, ibidem. Ibidem.

W istocie jedynym akceptowalnym podręcznikiem był ten autorstwa I. Andrejewa, L. Lernella i J. Sawickiego pt. Prawo karne Polski Ludowej, Warszawa 1950.

Kalendarz prac nad projektem kodeksu karnego (0.34). (AAN.MS. sygn. 285/1936).

Lista obecności na konferencji w dniu 14 listopada 1950 r., ibidem.

W piśmie prof. W. Woltera z dnia 15 listopada 1950 r. (do ministerstwa wpłynęło 20 listopada, U.3522/50/0.34/4/9) czytamy, że zdążył przygotować jedynie pierwszą część powierzonej mu problematyki przestępstw przeciwko życiu i zdrowiu, a więc kwestię zabójstwa. Pozostałe zagadnienia były już gotowe, jednak jeszcze nie przepisane na maszynie, ibidem.

Odpis pisma Nr U.3408/50/0.34/9/3 L. Lernella wskazującego, że przesłał on do członków Komisji tezy wraz z uzasadnieniem części ogólnej wraz z zaproszeniem na posiedzenie 14 listopada, ibidem. Z telegramu prof. W. Świdy z dnia 15 listopada wynika, że materiały miał przywieź w sobotę, czyli 18 listopada, ibidem.

Zaproszenie dla płk. Swiątkowskiego i płk. Zajcewa na dzień 17 listopada i 20 listopada, ibidem. Pismo prof. L. Schaffa do L. Lernella z dnia 28 stycznia 1951 r., ibidem.

Ibidem 
Była to bardzo trafna diagnoza oczekiwań ministerstwa. Trudno bowiem wyobrazić, że przy tak krótkich terminach można było pozwolić na dogłębne studia, a tym samym autentyczność poszczególnych rozwiązań. L. Schaff podniósł jeszcze bardzo istotną kwestię, a mianowicie konieczności wcześniejszego opracowania części ogólnej. Sprzeciwiał się takiej oto sytuacji, żeby poszczególne rozdziały części szczególnej opracowywać w oderwaniu od przepisów ustanawiających ogólne warunki odpowiedzialności karneje ${ }^{48}$. Dał tym samym dowód tego, że nie wiedział jaki miałby być jej przyszły kształt.

Korespondencja Schaffa z Lernellem przypadała na koniec stycznia 1951 roku, a więc czas kiedy prace nad poszczególnymi rozdziałami części szczególnej miały być $\mathrm{w}$ znacznym stopniu zaawansowania. Jak wynika bowiem z zachowanego fragmentu odpisu dokumentu zatytułowanego Kalendarz prac kodyfikacyjnych na miesiąc styczeń 1951 roku, między 5 stycznia a 5 lutego $1951 \mathrm{r}$. miały być opracowane tezy do większości grup przestępstw ${ }^{49}$. Tak jednak nie było, co czyniło dotrzymanie terminu realizacji całego projektu wielce wątpliwym. Czyniono jednak wszystko, aby zdążyć. Między innymi oddelegowano w dniach 6-9 lutego prof. Jerzego Sawickiego i dr. Igora Andrejewa do Krakowa w celu wykorzystania znajdujących się w Bibliotece Jagiellońskiej materiałów do opracowania problematyki przestępstw przeciwko godności i wolności człowieka i przeciwko zdrowiu i życiu ${ }^{50}$. Ten ostatni fakt oznaczał, że ministerstwo przestało polegać na Zakładzie Prawa Karnego Wydziału Prawa Uniwersytetu Jagiellońskiego, do którego należało przygotowanie problematyki przestępstw przeciwko życiu i zdrowiu. Wystąpiono także do Ministerstwa Oświaty i Sejmu Ustawodawczego o udzielenie sędzi Aleksandrze Kowalskiej wszelkich informacji potrzebnych przy opracowywaniu przez nią przestępstw przeciwko rodzinie i młodzieży ${ }^{51}$.

Pomimo podjętych działań termin realizacji całości projektu stawał się nadal coraz bardziej zagrożony. $Z$ tej przyczyny zwołano na dzień 20 lutego 1951 r. w ministerstwa specjalne spotkanie. Było to zebranie pracowników Departamentu Ustawodawczego uczestniczących w pracach nad kodyfikacją prawa karnego ${ }^{52}$. Jego tematem był stan zaawansowania prac. Jak wyraził się

„Jeżeli rozdział części szczególnej opracowywać w oderwaniu od części ogólnej powstać może niesamowity rozgardiasz" (AAN.MS. sygn. 285/1936). Ibidem.

50 Rękopis pisma L. Lernella do ministra sprawiedliwości z dnia 6 lutego 1951 r. Nr U 454/51/ 0.34/7/60 o delegację dla prof. J. Sawickiego i dr. I. Andrejewa, ibidem.

51 Odpis pisma L.Lernella do ministerstwa Oświaty z dnia 12 lutego 1951 roku, ibidem.

52 Udział wzięli: L. Lernell, I. Andrejew, S. Pławski, S. Kalinowski, A. Lipiński, H. Kluźniak, A. Kowalska, Z. Nyczaj, A. Rogulska, J. Sawicki, L. Kubicki, Protokót z zebrania pracowników Departamentu Ustawodawczego uczestniczacych w pracach kodyfikacyjnych prawa karnego odbytego w dniu 20 lutego 1951 roku, ibidem. 
sprawozdawca, I. Andrejew stan ten był zatrważający. Nie tylko nie przedyskutowano poszczególnych rozdziałów, ale wręcz większość nie była w ogóle opracowana. W zakresie części ogólnej sytuacja wyglądała lepiej, albowiem jej pierwsza redakcja była przygotowana. Takie tempo prac było jednak zdaniem Andrejewa niedopuszczalne ${ }^{53}$. Na usprawiedliwienie opóźnień referenci podawali przeróżne okoliczności od przeciągających prace i w zasadzie zbędnych merytorycznie konsultacji międzyresortowych (tak Henryk Kluźniak), po zbyt krótki okres i trudności techniczne z przygotowaniem maszynopisów (tak Stefan Kalinowski). Znacznie dalej w ocenie rzeczywistości posunął się S. Pławski. Nie tylko samokrytycznie podszedł do tempa i jakości swojej pracy, ale także podniósł, że nie tylko on przecenił swoje siły, ale także pozostali referenci. W znacznie mniej oględnych słowach wypowiedział się L. Lernell, który stwierdził, że „zespół kodyfikacyjny dzieli się na dwie kategorie pracowników. Grupę pracowników doświadczonych, odpowiedzialnych i grupę pracowników młodych. Winę za obecny stan prac kodyfikacyjnych przede wszystkim ponosi pierwsza grupa. Trzeba wyraźnie stwierdzić, że to co dotąd wykonano było robione powierzchownie, niesolidnie. Zbyt mało czasu przeznaczono na prace kodyfikacyjne (...) Grupa młodych niewątpliwie otrzymała zadania ponad jej siły. Było to jednak konieczne gdyż pierwsza grupa jest zbyt szczupła liczebnie. Należy jednak stwierdzić, że grupa młodych nie zrozumiała całkowicie swoich obowiązków, że grupa ta nie „żyje kodyfikacją", zbyt mało uwagi sprawom kodyfikacji poświęca"54. Poza powszechną deklaracją przyspieszenia prac ustalono, że każdy rozdział kodeksu powinien być opracowany także przez koreferenta. Postanowiono również powielić większą liczbę egzemplarzy tłumaczenia kodeksów RSFRR i krajów demokracji ludowej ${ }^{55}$.

Problemy z dotrzymywaniem terminów prac oraz krytyka postawy niektórych referentów na spotkaniu pracowników Departamentu Sprawiedliwości w lutym 1951 r. stały się powodem zwołania zebrania Komisji Konsultacyjno-Naukowej na dzień 31 marca 1951 r. ${ }^{56}$

Przedmiotem dyskusji miała być problematyka kodyfikacji prawa karnego, a więc zagadnienie, które $\mathrm{w}$ myśl uzasadnienia wniosku o podjęcie uchwały Prezydium Rządu z 27 września 1951 r. wydawało się być „dojrzałe” do realizacji. Efekty pierwszego półrocza prac kodyfikacyjnych były bowiem niezadowalające, co też świadczyło o niedojrzałości naukowej w rozumieniu marksistowsko-leninowskiego pojmowania prawa karnego. W zebraniu uczestni-

53 Ibidem, s. 1.

54 Ibidem, s. 3-4.

55 Ibidem, s. 4

56 Protokół zebrania Komisji Konsultacyjno-Naukowej z dnia 31 marca 1951 r. - rękopis (dalej: Protokół KKN z 31 marca 1951 r.), (AAN. MS. sygn. 285/5467). 
czyło 54 profesorów i pracowników naukowych, a także przedstawiciele sądownictwa i prokuratury ${ }^{57}$.

Wprowadzenie do dyskusji stanowił referat L. Lernella ${ }^{58}$. W swoim wystąpieniu w pierwszej kolejności powtórzył, że zadaniem powołanych organów jest opracowanie nowego kodeksu karnego, a nie nowelizacja czy inkorporacja istniejących przepisów prawa karnego ${ }^{59}$. Oświadczenie tego rodzaju stanowiło jednocześnie samokrytyczne podejście do zapatrywania na problem kodyfikacji prawa karnego materialnego w okresie 1947-1950. Na marginesie warto jednak zaznaczyć, że referentowi akurat można było najmniej „zarzucić”, ponieważ jako jeden $\mathrm{z}$ nielicznych zdawał sobie wówczas sprawę z problemu. Niemniej dokonał samokrytyki oraz zwrócił się z apelem o uczynienie tego samego do innych. Ku jego zdziwieniu nie wszyscy jednak poczuli taką potrzebę

W swoich rozważaniach L. Lernell odniósł się jednak także do zagadnień szczegółowych, które $\mathrm{w}$ istocie stanowiły o problemie opracowania nowego kodeksu, a to:

1) stosunku k.k, z 1932 r. do nowych przepisów karnych PRL;

2) stosunku nowych przepisów karnych PRL do zamierzeń kodyfikacyjnych;

3) stosunku prawa karnego PRL do prawa karnego ZSRR;

4) stylu i języka przyszłego kodeksu' ${ }^{61}$.

Odnosząc się do pierwszego zagadnienia naczelnik Lernell podkreślił, że niesłuszny jest pogląd jakoby precyzja, stylistyka i walory techniczne tego kodeksu przemawiały za traktowaniem go jako wzoru lub „tworzywa" dla nowego kodeksu PRL. Polecił, aby poddać „ostrej klasowej krytyce” wszystkie instytucje tego kodeksu i dopiero po odrzuceniu tego całego „balastu burżuazyjnego", tych "ogonów" należy przystąpić do opracowania nowych instytucji przyszłego kodeksu62. Miał ponadto stwierdzić, że "Nic nas nie łączy z tym kodeksem! Nie chcemy go znać!" Paradoksalnie jednak taki pogląd zakładał,

57 P. Fiedorczyk, op. cit., s. 263. L. Lernell, Z problematyki kodyfikacji prawa karnego (rozważania ogólne), (AAN.MS. sygn. 5476).

58 Zagadnienia metodologiczne kodyfikacji prawa karnego (Zebranie Komisji Konsultacyjno-Naukowej w dniu 31 marca 1951 r.), „Nowe Prawo” (dalej: NP) 1951, nr 5, s. 54-58; L. Lernell, Z problematyki kodyfikacji prawa karnego (Rozważania metodologiczne), cz. I, „Państwo i Prawo” (dalej PiP) 1951, z. 4, s. 640-664; idem, Z problematyki kodyfikacji prawa karnego (Rozważania metodologiczne), cz. II, PiP 1951, z. 5-6, s. 841-853; idem, Z problematyki kodyfikacji prawa karnego (rozważania ogólne) - (AAN.MS. sygn. 285/5476)

59 Ibidem; Zagadnienia metodologiczne kodyfikacji..., s. 54; L. Lernell, op. cit., s. 644.

60 A. Bachrach odnosząc się do zarzutów L. Lernella stwierdził: „Nie mogę zastosować się do apelu dyrektora Lernella o samokrytykę, ponieważ nie mam na sumieniu ani błędów, ani zasług $\mathrm{w}$ pracy toczącej się nad kodyfikacją prawa karnego. Korzystam z pierwszej okazji, aby zabrać głos w tej doniosłej sprawie, raczej z pozycji outsidera, co prawda bardzo zainteresowanego $\mathrm{w}$ wynikach prac kodyfikatorskich". A. Bachrach, Referat, s. 1 (AAN. MS. sygn. 285/5467).

62 Ibidem, s. 3. 
że nie opowiadał się za wyrzuceniem kodeksu Makarewicza na „śmietnik historii" i rozpoczęcie prac od zera, co nawet w ojczyźnie rewolucji proletariatu było niewykonalne. Zdawał sobie $\mathrm{z}$ tego doskonale sprawę, choć wprost tego nie powiedział. Świadczy o tym ta „klasowa krytyka” przepisów kodeksu, która nie wykluczała przejęcia przynajmniej części jego rozwiązań.

Stosunek Lernella do przepisów wydanych w okresie powojennym był również krytyczny. Uważał bowiem, że chociaż służą one coraz skuteczniej ochronie podstawowych funkcji państwa ludowego, to jednak nie są one dostatecznie ani pod względem treści, ani formy, przede wszystkim jeżeli chodzi o ochronę mienia socjalistycznego. Cytując prof. Goliakowa powiedział: „Im szersze są perspektywy zwycięstw $\mathrm{w}$ walce o komunizm, tym bardziej stanowcze winny być środki przymusu w stosunku do nosicieli tradycji kapitalizmu". Istotna była również forma, albowiem prawo socjalistyczne ma spełniać rolę wychowawczą, dlatego winno uwypuklać treść klasową norm i charakterystykę polityczną ${ }^{63}$.

„Prawo i nauka radziecka wzorem i przykładem" 64 . To miało być remedium na wszelkie problemy kodyfikacyjne PRL. Lernell jednak przestrzegał przed wszelkim automatyzmem $\mathrm{w}$ tym zakresie, albowiem jego zdaniem należało mieć na względzie odmienności faz rozwojowych i form dyktatury proletariatu w ZSRR i PRL. Dotyczyło to również innych krajów demokracji ludowej65.

Minister Świątkowski zabierając głos po Lernerze poparł jego stanowisko względem kodeksu karnego z 1932 roku, natomiast wywód odnośnie powojennego ustawodawstwa uznał za niepełny ${ }^{66}$. $Z$ tego względu przedstawił swoją analizę, która była bardziej konkretna od tej przedstawionej przez naczelnika Lernella.

Świątkowski wskazał, że przepisy karne powojenne były dalekie od doskonałości ideologicznej, albowiem wówczas „nie było nas stać na analizę teoretyczną państwa i prawa" ${ }^{67}$. Zapytał w związku z tym wręcz retorycznie: „Czy w 1944 roku byli u nas prawnicy o przygotowaniu marksistowskim?" I na tak postawione pytanie odpowiedział: „Nie było ich i to zaciążyło na wydanych w tym okresie przepisach"68. Zwrócił również uwagę na wpływ odchylenia prawicowo-nacjonalistycznego, które wprowadziło zamęt ideologiczny na drodze rozwoju państwa ludowego ${ }^{69}$.

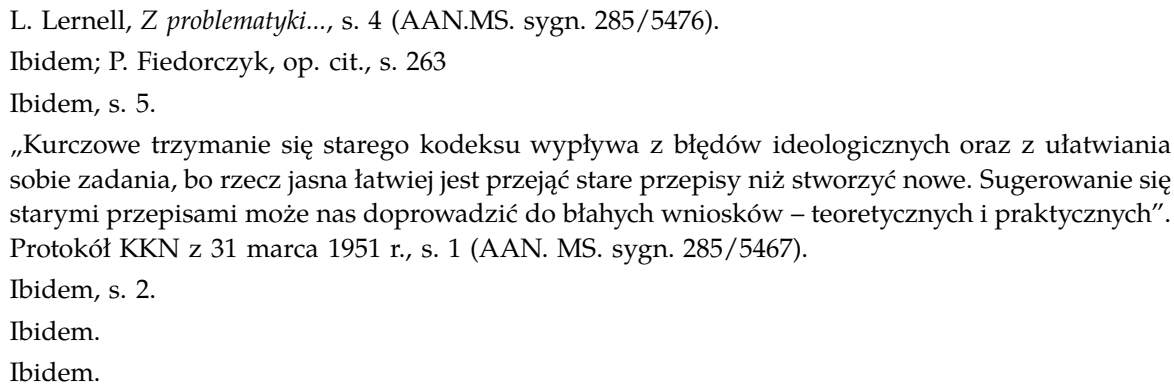


Minister Świątkowski nie tylko poprzestał na wykazaniu tła problemu, ale także zarzucił prawnikom, że zamiast rozmawiać o prawie radzieckim, dyskutowano o prawie francuskim i szwajcarskim ${ }^{70}$. Popierając Lernella wskazał, że to właśnie prawo radzieckie ma być "busolą" wytaczającą kierunek polskiego prawa ${ }^{71}$. Podobnie jak przedmówca nie wypowiedział się konkretnie co do zakresu wzorowania się na prawie ZSRR. Stwierdził jedynie, że "obecnie mamy sytuację przeginania tak $w$ jedną jak i w drugą stronę", co należy interpretować również jako przestrogę przed wszelkim bezrefleksyjnym automatycznym kopiowaniem.

Po wystąpieniach gospodarzy konferencji, a więc ministra H. Świątkowskiego i L. Lernella nastąpiła dyskusja ${ }^{72}$. I chociaż często zbaczała ona w stronę bardzo szczegółowych kwestii i konkretnych przepisów kodeksu karnego, to jednak przede wszystkim chodziło $w$ niej o rozważenie zagadnień metodologicznych pracy kodyfikacyjnej ${ }^{73}$. Głos zabrali m.in. Aleksander Bachrach, T. Kurowski, Stanisław Śliwiński, Henryk Podlaski i Henryk Rajzman, Jerzy Sawicki, Marian Cieślak i W. Wolter ${ }^{74}$. Zapowiedź stanowiska na piśmie w formie referatu złożyli: Marian Muszkat, Emil Stanisław Rappaport, L. Schaff i W. Wolter ${ }^{75}$. $\mathrm{W}$ wypowiedziach oraz referatach pisemnych poruszono bardzo wiele problemów, z których część stanowiła powtórzenie tez L. Lernella, ale także pojawiły się nowe zagadnienia, stanowiące konsekwencję tych pierwszych. Sprowadzały się one do następujących pytań:

1) Jaki jest nasz aktualny stosunek do k.k. z 1932 r.?

2) W jakiej fazie rozwoju państwa ludowego się znajdujemy?

3) Na jak długo mamy przygotowywać kodeks karny?

4) Jakim językiem powinien być napisany kodeks karny?

5) Czy prawo karne wojskowe i karnoskarbowe powinny być poza kodeksem? Igor Andrejew nazwał k.k. z 1932 r. „podstarzałą uszminkowaną śpiewaczką, która z konieczności grając rolę młodej przodownicy pracy musi bardzo markować"76. „Markować” wedle Andrejewa znaczyło tyle, co maskować, zakrywać, a chodziło mu o takie instytucje jak środki zabezpieczające czy też konkretne artykuły części szczególnej, jego zdaniem o charakterze sanacyjnym (art. 137), klerykalnym (art. 172 i art. 198) i feudalnym (art. 272) ${ }^{77}$.

\footnotetext{
70 Ibidem.

71 Protokół KKN z 31 marca 1951 r., s. 2 - (AAN. MS. sygn. 285/5467).

72 Ibidem, s. 5.

73 Ibidem, s. 5-6.

74 Trudno powiedzieć czy to wszystkie osoby, które zabierały głos w dyskusji, ponieważ rękopis protokołu jest niekompletny.

75 Ibidem, s. 9.

76 I. Andrejew, Referat, s. 1 (AAN. MS. sygn. 285/5467).

77 Ibidem, s. 2.
} 
Taki trochę ironiczny stosunek Andrejewa do kodeksu Makarewicza nie oznaczał, że postulował on całkowite odcięcie się od niego. Bardzo wyraźnie podkreślił, że istnieje w nim bardzo wiele przepisów, które znajdą swój dosłowny odpowiednik $w$ nowym kodeksie socjalistycznym. Tym samym wpisywał się w pogląd, że samo umiejscowienie określonego rozwiązania prawnego tak w kodeksie Makarewicza, jak i kodeksie RSRR nie może oznaczać wcale automatycznego odrzucenia lub bezrefleksyjnej recepcji ${ }^{8}$.

Niejednoznaczność stanowiska L. Lernella oraz wszystkich, którzy uznawali je za słuszne (tak m.in. Andrejew i Wolter) wykazał A. Bachrach ${ }^{79}$. Zwrócił on uwagę na okoliczność, że z referatu Lernella nie wynikało wcale $w$ jakiej fazie, czy etapie rozwoju państwa socjalistycznego się znajduje Polska Ludowa i w ogóle co to znaczy ${ }^{80}$. Wyszczególniając sprzeczności odnośnie kryteriów periodyzacji rozwoju państwa socjalistycznego stwierdził bowiem, że w istocie to nie wiadomo czy ludowe państwo polskie jest w pierwszej fazie czy już ją przekroczyło. Co więcej, zarzucił Lernellowi, że powoływanie się na uczonych radzieckich w tym zakresie jest błędne, ponieważ dyskusja w Radzie Naukowej Wszechzwiązkowego Instytutu Nauk Prawnych i Rady Redakcyjnej Państwowego Wydawnictwa Literatury Prawniczej wykazała, iż periodyzacja państwa radzieckiego z punktu widzenia nauki stalinowskiej o fazach rozwojowych państwa była mechaniczna i fałszywa ${ }^{81}$.

Fazy (etapy) rozwoju państwa socjalistycznego to nie jedyny obszar krytyki ze strony Bachracha. Zarzucił on bowiem Lernellowi przede wszystkim brak konsekwencji i sprzeczności w podejściu do „starych norm prawnych". Jego zdaniem Lernell z jednej strony określał stare przepisy mianem "ogonów”, które należy nie tylko nie recypować, ale wręcz eliminować, a z drugiej mówił o ich stopniowym zanikaniu i zastępowaniu lub wręcz nabieraniu przez nie „nowej treści”. Skoro zatem Lernell nie wypowiadał się za całkowitym nihilizmem prawnym, a jednocześnie nie chciał włączania „starych norm” do nowego kodeksu karnego, bo one będą zanikać, to Bachrach sformułował pod adresem referenta bardzo konkretne pytanie: „Gdzie będą więc one (te normy - T.S.) zanikać? ${ }^{82}$ Pytanie to pozostało jednak bez odpowiedzi, z czego można wyciągnąć wniosek, że referent Lernell zdawał sobie sprawę z konieczności przejęcia bardzo wielu rozwiązań prawnych okresu burżuazyjnego, choć oczywiście powiedzenie tego wyraźnie byłoby z jego strony politycznie niedopuszczalne.

\footnotetext{
78 Ibidem, s. 3

79 A. Bachrach, Referat $n r$ 1, s. 1-17; idem, Referat $n r$ 2, s. 1-7 (AAN. MS. sygn. 285/5467).

80 A. Bachrach, Referat nr 1, s. 2.

81 Ibidem, s. 4.

82 A. Bachrach, Referat nr 1, s. 6.
} 
Krytyka Bachracha miała jednak również swoją diagnozę. W jego mniemaniu Lernell popełnił "grzech pierworodny" utożsamiając pojęcie "recepcji lub kontynuacji prawa burżuazyjnego" z pojęciem „recepcji lub kontynuacji norm prawa burżuazyjnego" ${ }^{\prime \prime 3}$. Zdaniem Bachracha powodem tego stanu był lęk Lernella przed zarzutem recepcji prawa burżuazyjnego. Wedle opinii Bachracha było to nieuzasadnione, gdyż jak stwierdził „norma wyjęta z jakiegoś systemu nie posiada własnego życia społecznego" ${ }^{84}$. Co więcej, stwierdził, że norma wyjęta z burżuazyjnego systemu prawnego może być nieprzydatna, ale nie musi taka być. Takie rozumowanie zaprowadziło go do konstatacji odnośnie kodeksu z 1932 r.: „Nie ma się po prostu czym zachwycać, ale też nie ma się czego lękać" 85 . Co więcej, był zdania, że nie tylko nie można jeszcze sobie pozwolić na wyeliminowanie wielu norm części szczególnej k.k. z 1932 r., ale że wręcz należy tworzyć nowe, aby skutecznie walczyć z nowymi zjawiskami przestępczymi ${ }^{86}$. Przestępczość charakterystyczna dla ustroju kapitalistycznego nie zniknęła, a pojawiły się nowe stany faktyczne i na nich powinna się skupiać praca kodyfikacyjna. Była to jednocześnie odpowiedz na postawione Lernellowi pytanie odnośnie zanikania norm prawa karnego w rozwoju państwa ludowego. Wizja nowego kodeksu, jaką zaproponował, przedstawiała się oto tak, że część ogólna kodeksu Makarewicza musi ulec zasadniczym zmianom, albowiem w niej wyrażone są generalne zasady prawa karnego, natomiast na część szczególną składałyby się przepisy traktujące o przestępstwach właściwych dla okresu burżuazyjnego jak i te nowe. Warto zaznaczyć, że było to zupełnie inne podejście do kodyfikacji niż w „zapomnianym okresie” 1947-1950.

Nie mniej emocji w dyskusji wywołała kwestia tego, na jak długo należy tworzyć kodeks karny. Lernell był w tym zakresie mało precyzyjny sugerując jednak, że kodeks powinien odpowiadać „,aktualnemu stopniu natężenia walki klasowej i form tej walki” oraz spełnić „poważną rolę w walce o realizację Planu Sześcioletniego" ${ }^{\prime \prime 7}$. H. Podlaski był z kolei zdania, że kodeks należy przygotować na okres do zbudowania socjalizmu ${ }^{88}$. Jeden i drugi pogląd - przynajmniej od strony ideologicznej - wskazywał na stosunkowo krótki okres obowiązywania, co skwitował śmiechem A. Bachrach: „Chcielibyście jak najkrócej!" 89. Reakcja ta pokazywała, że nikt nie brał poważnie stosunkowo szybkiego przejścia do socjalizmu, a już w ogóle abstrakcyjnie wyglądała perspektywa komu-

83 A. Bachrach, Referat nr 1, s. 7.

84 „Norma części szczególnej prawa karnego w oderwaniu od systemu i stosunków, którym on służy - to po prostu idealne i abstrakcyjne uogólnienie, odbicie pewnych faktów społecznych", ibidem.

Ibidem, s. 8.

Ibidem, s. 11

Ibidem, s. 14; L. Lernell, Z problematyki..., s. 8 (AAN.MS. sygn. 285/5476).

A. Bachrach, Referat $n r$ 2, s. 4-5.

Ibidem. 
nizmu, który to miał przecież funkcjonować nie tylko bez prawa karnego, ale prawa w ogóle.

W opozycji do poglądów Lernella i Podlaskiego pozostawał jednak nie tylko Bachrach, ale także W. Wolter, który opowiedział się za opracowywaniem kodeksu, który powinien obowiązywać jak najdłużej ${ }^{90}$. Nie zmienia to jednak faktu, że i on upatrywał w nim cech właściwych dla każdej ustawy socjalistycznej, a więc ograniczonego czasookresu jej obowiązywania. Nie mniej jednak za absurdalne uznał założenie, wedle którego spodziewając się przejścia do komunizmu, należałoby już teraz przygotowywać tak kodeks, aby on "zamierał"91. I chociaż nie miał to być - jak dosadnie wyraził się Bachrach "twór spiżowy", a więc wieczny, to jednak nikt nie był wstanie powiedzieć na jak długo należy go opracowywać. Zdroworozsądkowe podejście Woltera wydawało się więc najlepsze.

Kolejne zagadnienie jakie poruszono dotyczyło języka przyszłego kodeksu. Niewątpliwie nawet wyraźnie ideologicznie nastawieni członkowie komisji jak Lernell czy Andrejew nie potrafili zaprzeczyć, że od tej strony kodeks Makarewicza był dziełem wybitnym ${ }^{92}$. Dla L. Lernella przyszły kodeks karny powinien operować językiem „dostępnym i jasnym dla szerokich mas"93. Czy zatem język k.k z 1932 r. mógł być wykorzystany? Tak, albowiem jak przekonywał Lernell powołując się na Stalina, ,język nie stanowi ani elementu bazy ani nadbudowy, a zatem może "obsługiwać" różne bazy i nadbudowy ${ }^{94}$. Bardzo wyraźnie w tym względzie wypowiedział się już wcześniej Andrejew, który przestrzegał przed bezrefleksyjnym odrzucaniem rozwiązań prawnych tylko dlatego, że znajdują się one w kodeksie burżuazyjnym, czy odwrotnie w kodeksie socjalistycznym ${ }^{95}$.

Walory stylistyczne i syntetyczna precyzja językowa kodeksu z 1932 r. to jedno, ale zrozumiałość przepisów dla mas to już inna kwestia. Lernell zapewne zdążył już przyzwyczaić odbiorców swoich wystąpień do skrajnie idealistycznego podejścia odnośnie kwestii prawnych nowej rzeczywistości, dlatego jego „recepta” w tym względzie wywołała ożywioną reakcję M. Cieślaka i W. Woltera. Jakkolwiek nie podważali idei zrozumiałości i dostępności języka ustawy karnej, to jednak dalecy byli od przyznawania jej pierwszeństwa przed precyzją i ścisłością̨ ${ }^{96}$. Wolter wyraził ten problem bardzo dobitnie, stwierdza-

90 W. Wolter, Referat, s. 2

91

Ibidem.

I. Andrejew, Referat, s. 1

L. Lernell, Z problematyki..., s. 6-7.

Ibidem, s. 7.

Ibidem, s. 3.

96 „Nie należy się bowiem łudzić, iż kodeks karny stanie się kiedykolwiek popularną lekturą, rozchwytywaną i czytaną chętnie przez masy", M. Cieślak, Referat, s. 3; identycznie W. Wolter, Referat, s. 4 . 
jąc, że „maksymalna zrozumiałość dla ogółu nie musi bowiem iść w parze z maksymalną precyzją, a skąpstwo słowne, tak ważne dla precyzji, nie ułatwia zrozumienia; wielomówność łatwo stać się może źródłem chwiejności. O ile więc te postulaty skrzyżują się ze sobą, to ze względu na wagę stosowania prawa nie wahałbym się przyznać pierwszeństwo postulatowi precyzji"97. Ciekawe stanowisko $\mathrm{w}$ tej kwestii zajął Józef Lipczyński. Skonstruował bowiem koncepcję wedle której, część ogólna co do zasady miałaby posługiwać się językiem precyzyjnym - techniczno-prawnym - natomiast adresowana do mas część szczególna - językiem popularnym ${ }^{98}$. Takie stanowisko rodziło nadzieję, że większość konstrukcji prawniczych i pojęć z nimi związanych, wypracowanych przez międzywojenną Komisję Kodyfikacyjną właśnie w odniesieniu do części ogólnej, pozostanie niezmieniona. Inaczej, jeżeli chodzi o część szczególną, której kształt w świetle poglądów Lipczyńskiego jawił się jako daleki od syntetycznych sformułowań, z tendencją do rozwlekłości i opisowości. I chociaż miały pojawić się nowe pojęcia takie jak „plan”, „mienie społeczne”, dyscyplina pracy, oraz nowe typizacje przestępstw części szczególnej, jednak o tworzeniu zupełnie nowej terminologii prawniczej kodeksu nie mogło być mowy ${ }^{99}$.

Pomimo faktu, że wszyscy wyrażali swój podziw dla konstrukcji językowej przepisów kodeksu z 1932 r., pojawiła się także kwestia przyjęcia za wzorem radzieckim tzw. uwag do poszczególnych przepisów ustawy karnej. Zastosowanie takiej techniki zaaprobował M. Cieślak ${ }^{100}$. Z krytyką wystąpił S. Śliwiński i A. Bachrach. Ten ostatni podkreślił, że w przeciwieństwie do prawa rosyjskiego, takie rozwiązanie nie ma nic wspólnego $\mathrm{z}$ naszą narodową tradycją kodyfikacyjną ${ }^{101}$.

Odnośnie kwestii utrzymania odrębności względem kodeksu karnego takich dziedzin jak prawo karne wojskowe i karne skarbowe, stanowisko Lernella było jasne. Opowiedział się za ich pełną integracją $w$ ramach jednego powszechnego kodeksu' ${ }^{102}$. Marian Muszkat uznał ten postulat za co do zasady dojrzały do realizacji jeżeli chodzi o wspólną część ogólną, jednak zaznaczył, że ewentualna integracja przepisów prawa wojskowego powinna odbyć się w porozumieniu z sądowo-prokuratorskimi władzami wojskowymi ${ }^{103}$. Kwestią całkowicie otwartą pozostawała nadal sprawa, czy umieszczać w kodeksie

97 W. Wolter, Referat, s. 3-4.

"Zaznaczam tutaj, że utrzymanie tych «starych instytucji» nie musi być sprzeczne z nową treścią klasową. Instytucja «podżegania» może obsługiwać każdą klasę". J. Lipczyński, Notatka do protokołu $z$ dnia 31 marca 1951 r., s. 1-2.

99 Ibidem.

100 M. Cieślak, Referat, s. 5-6.

101 „Potrzebne nam jest prawo socjalistyczne w swej treści, ale w formie niechaj będzie najbardziej narodowe". A. Bachrach, Referat $n r$ 2, s. 2.

102 L. Lernell, Z problematyki..., s. 2.

103 M. Muszkat, Referat, s. 1-2. 
karnym rozdział poświęcony przestępstwom ściśle wojskowym czy też pozostawić je poza w postaci nadal odrębnego kodeksu karnego wojskowego ${ }^{104}$. Za całkowitym utrzymaniem odrębności tych dziedzin opowiedział się Stanisław Śliwiński, choć bez szczególnego uzasadnienia ${ }^{105}$.

Posiedzenie Komisji Konsultacyjno-Naukowej zakończyło się w godzinach wieczornych. Podsumowanie dyskusji dokonał główny referent L. Lernell. Jak sam przyznał jeden $\mathrm{z}$ dwóch celów jakie przyświecały zwołanej konferencji został zrealizowany, a mianowicie rozbudzenie dyskusji wśród teoretyków w przedmiocie zasadniczych problemów kodyfikacyjnych. Drugi cel, a mianowicie uzyskanie konkretnej pomocy $\mathrm{w}$ rozwiązaniu dyskutowanych zagadnień nie powiódł się ${ }^{106}$. Lernell zarzucił obecnym, że ich rozważania zbyt często koncentrowały się na szczegółowych problemach czy poszczególnych przepisach, a chodziło przecież o to jakie zająć stanowisko względem „starych" norm prawnych i jak w ogóle budować nowy kodeks karny ${ }^{107}$.

Lernell był wyraźnie zawiedziony. Liczył na pomoc teoretyków, a pozostał z problemami sam. Sytuacja przypominała trochę tę, jaka miała miejsce w okresie 1947-50, z tą jednak zasadniczą różnicą, że aktualnie nie mogło być mowy o nieporozumieniu. Wszyscy wiedzieli, że należy budować nowy kodeks karny Polski Ludowej i na ogół - poza Bachrachem - zgadzali się ze stanowiskiem referenta, lecz ich ogólne stanowiska nie rozwiązywały wątpliwości Lernella, który stojąc przed koniecznością opracowania części ogólnej i redakcją tekstu całego projektu, musiał podjąć konkretne decyzje. Dlaczego nie mógł liczyć na wsparcie innych? Najbardziej prawdopodobnym powodem był po prostu brak pomysłu rozwiązania zaprezentowanych przez Lernella kwestii. Propozycja L. Schaffa sformułowania zupełnie nowego systemu prawa karnego w oparciu o dotychczasowy dorobek nauki, o ile „nie zniekształci to treści klasowej poszczególnych przepisów" wydawała się w ówczesnych warunkach politycznych słuszna, lecz i tak nie rozwiązywała problemu Lernella. Z punktu widzenia ideologicznego takie propozycje „na papierze” wyglądały prawidłowo, jednak ewidentnie L. Lernellowi brakowało know-how konkretnych rozwiązań prawnych. Problem ten wyraził dosadnie M. Muszkat, który choć uznał, że należy w pracach kodyfikacyjnych oprzeć się na założeniach marksistowsko-leninowskich $\mathrm{z}$ uwzględnieniem doświadczeń radzieckich, to jednak przyznał, że nie jest $\mathrm{w}$ stanie pozytywnie wypowiedzieć się co do tego jak to zrobić108. Ta szczera diagnoza dotyczyła tak problemu wykorzystania dorobku prawnego ZSRR, jak i stosunku do obowiązującego rodzimego

\footnotetext{
104 M. Muszkat, Referat, s. 2.

105 S. Śliwiński, Referat, s. 2.

106 Protokół KKN z 31 marca 1951 r. (rękopis, brak numeru strony) AAN. MS. sygn. 285/5467.

107 Ibidem.

108 M. Muszkat, Referat, s. 10.
} 
ustawodawstwa karnego. Wbrew jednak oczekiwaniom Muszkata, problemy te jedynie zdiagnozowano, ale nie rozwiązano ${ }^{109}$. W takiej sytuacji jedynym rozwiązaniem pozostawało sięgnięcie do zdobyczy innych krajów demokracji ludowej i ZSRR, przynajmniej do czasu, gdy ustalenia I Kongresu Nauki Polskiej zaczęłyby przynosić wymierne efekty.

Pomimo problemów, projekt części ogólnej kodeksu karnego został opublikowany w zakreślonym przez uchwałę z 27 września rocznym terminie. Nie był to oczywiście cały kodeks. Problemy bowiem, jakie pojawiały się w związku z opracowaniem całości projektu otwierały drogę do zjawiska „kawałkowanej kodyfikacji", a więc wydawania szeregu okołokodeksowych aktów prawnych, stanowiące "reakcję" na aktualne problemy społeczne, gospodarcze i polityczne Polski Ludowej. Prawo karne miało być bowiem „regulatorem" i „kreatorem” nowej rzeczywistości, niezależnie od postępów w opracowywaniu socjalistycznego kodeksu karnego ${ }^{110}$.

\section{Zakończenie}

W początkach Polski dosyć popularny był pogląd, że w "stare normy", które miały stanowić tylko formę, rewolucja "wlała” nową treść, zgodnie z interesem państwa ludowego, co też miało stanowić uzasadnienie ich obowiązywania ${ }^{111}$. Przebieg prac nad pierwszym projektem kodeksu karnego, a zwłaszcza polemika osób w tym przedsięwzięciu uczestniczących, pokazała jednak, że zupełnie inaczej wyglądała sprawa "dostosowywania się" prawników "starej nadbudowy" do zupełnie odmiennej bazy. Niewątpliwie łatwiej było nadać nową treść starym przepisom, niż "starych" prawników przekonać do marksizmu i leninizmu w pojmowaniu prawa i jego kodyfikacji. "Starzy” prawnicy byli jednak potrzebni, a "młodych", czyli w pełni uświadomionych ideologicznie wciąż było mało, co dobitnie stwierdzono na posiedzeniu $\mathrm{w}$ ministerstwie w lutym $1951 \mathrm{r}$. Fakt ten podniósł do rangi zarzutu pod adresem środowiska naukowego, minister Świątkowski na zebraniu Komisji Konsultacyjno-Naukowej z 31 marca.

W. Wolter starał się być neutralny i ostrożny w osądach, koncentrując swoją uwagę na zagadnieniach logicznych i metodologicznych kodyfikacji. I wreszcie L. Lernell, który chociaż z racji pełnionej funkcji w ministerstwie nie miał nie mógł mieć - problemów ze zrozumieniem „nowej bazy”, to jednak brakowało mu konkretnego pomysłu, jak jej założenia przekuć w przepisy zupełnie nowego socjalistycznego kodeksu karnego.

109 Ibidem, s. 11.

110 A. Lityński, Pół wieku kodyfikacji prawa w Polsce (1919-1969). Wybrane zagadnienia, Tychy 2001, s. 55.

111 D. Maksimiuk, op. cit., s. 142. 
Powyższa sytuacja nie rodziła nadziei na udane, a co równie wówczas ważne, szybkie powstanie nowej kodyfikacji karnej materialnej112. I chociaż ostatecznie pierwszy projekt kodeksu karnego powstał, to i tak wciąż atrakcyjna z punktu widzenia władzy okazywała się być droga tzw. kawałkowanej kodyfikacji, która wolna od sporów metodologicznych i ideologicznych stanowiła szybkie remedium na aktualne potrzeby państwa ludowego w zakresie prawa karnego.

\section{Bibliografia}

\section{Źródła}

Archiwum Akt Nowych w Warszawie, zespół Ministerstwo Sprawiedliwości

AAN, MS, sygn. 285/1791.

AAN, MS, sygn. 285/1792.

AAN, MS, sygn. 285/1937.

AAN, MS. sygn. 285/1814.

AAN, MS. sygn. 285/1936.

AAN, MS. sygn. 285/1941.

AAN, MS. sygn. 285/1942.

AAN, MS. sygn. 285/5467.

AAN, MS. sygn. 285/5476.

\section{Projekty}

Projekt kodeksu karnego Polski Ludowej. Część ogólna, Warszawa 1951.

Projekt kodeksu karnego Polskiej Rzeczypospolitej Ludowej i przepisy wprowadzajace, Warszawa 1956.

\section{Akty prawne}

Monitor Polski 1950 rok, Nr A-106, poz. 1339.

\section{Literatura}

I. Andrejew, Nowy kodeks karny. Z rozważań nad projektem, Warszawa 1963. 
P. Fiedorczyk, Z dziejów stalinizacji polskiej nauki prawa. Komisja Konsultacyjno-Naukowa przy Ministrze Sprawiedliwości (1949-1951), [w:] Konstytucjonalizm, Doktryny, Partie Polityczne. Ksiega dedykowana Profesorowi Andrzejowi Ziębie, red. R. Kłosowicz, B. Kosowska-Gąstoł, G.M. Kowalski, T. Wieciech, Ł. Jakubiak, Kraków 2014.

L. Lernell, Kodyfikacja czy reforma prawa karnego?, „Demokratyczny Przegląd Prawniczy" 1947, nr 4.

L. Lernell, Uwagi o nowelizacji i kodyfikacji prawa karnego. Czy konieczna reforma części ogólnej k.k.?, „Demokratyczny Przegląd Prawniczy” 1947, nr 10.

L. Lernell, Z problematyki kodyfikacji prawa karnego (Rozważania metodologiczne), cz. I, „Państwo i Prawo” 1951, z. 4.

L. Lernell, Z problematyki kodyfikacji prawa karnego (Rozważania metodologiczne), cz. II, „Państwo i Prawo” 1951, z. 5-6.

A. Lityński, O prawie i sądach początków Polski Ludowej, Białystok 1999.

A. Lityński, Pół wieku kodyfikacji prawa w Polsce (1919-1969). Wybrane zagadnienia, Tychy 2001.

D. Maksimiuk, Z problematyki kodyfikacji prawa karnego materialnego początków Polski Ludowej, „Miscellanea Historico-Iuridica” 2009, t. 7.

A. Stawarska-Rippel, Co czynić ze starym prawem? Problem ciagłości prawa sądowego w poczatkach Polski Ludowej, „Miscellanea Iuridica” 2004, t. 5.

S. Śliwiński, W sprawie reformy prawa karnego. Nowelizacja przepisów dotyczacych zasad odpowiedzialności, „Demokratyczny Przegląd Prawniczy” 1947, nr 11.

Zagadnienia metodologiczne kodyfikacji prawa karnego (Zebranie Komisji Konsultacyjno-Naukowej w dniu 31 marca 1951 r.), „Nowe Prawo” 1951, nr 5. 